Email: jkesislam@unisma.ac.id

Home Page : http://riset.unisma.ac.id/index.php/jki

\title{
KORELASI ANTARA KUALITAS SKENARIO DAN KEEFEKTIFAN DISKUSI TUTORIAL TERHADAP PRESTASI AKADEMIK MAHASISWA
}

Lailia Izza Oktavia Purhadi, Rizki Anisa*, Marindra Firmansyah

Fakultas Kedokteran Universitas Islam Malang

\begin{abstract}
ABSTRAK
Pendahuluan:. Terdapat beberapa faktor internal maupun eksternal yang mempengaruhi prestasi akademik mahasiswa. Salah satunya yaitu metode pembelajaran Problem Based Learning PBL khususnya kualitas skenario dan keefektifan diskusi kelompok tutorial. Tujuan penelitian ini adalah mengetahui korelasi antara kualitas skenario dan keefektifan diskusi terhadap prestasi akademik Mahasiswa Fakultas Kedokteran UNISMA.

Metode: Desain deskriptif analitik pendekatan cross sectional. Data primer didapatkan dari kuesioner kualitas skenario dan keefektifan diskusi yang telah tervalidasi sedangkan data prestasi akademik didapatkan dari program studi kedokteran. Sampel penelitian sejumlah 490 mahasiswa. Analisis bivariat menggunakan uji korelasi spearman untuk menguji korelasi antara keefektifan diskusi dan kualitas skenario terhadap prestasi akademik dan uji regresi linier berganda untuk menguji faktor yang mempengaruhi prestasi akademik.

Hasil: Pada uji korelasi spearmen didapatkan $P$-value $<0.05$ artinya terdapat korelasi antara kualitas skenario dengan nilai prestasi akademik. Hasil uji korelasi antara keefektifan diskusi dengan prestasi akademik mahasiswa didapatkan $P$-value $<0.05$ sehingga terdapat korelasi antara keefektifan diskusi dengan prestasi akademik.

Perbedaan kualitas skenario dan keefektifan diskusi terhadap prestasi akademik dengan uji regresi linier berganda didapatkan, keefektifan diskusi lebih berpengaruh signifikan dibandingkan kualitas skenario terhadap prestasi akademik mahasiswa dengan nilai $P$ value $<0,05$

Kesimpulan: Kualitas skenario dan keefektifan diskusi sama sama berpengaruh signifikan terhadap presstasi akademik dengan kekuatan yang lebih baik pada keefektifan diskusi.
\end{abstract}

Kata kunci : Prestasi Akademik, kualitas skenario, keefektifan diskusi tutorial.

*Korespondensi :

Rizki Anisa

Jl. MT. Haryono 193 Malang, Jawa Timur, Indonesia, 65144

email : rizky.anisa@ unisma.ac.id, Telpon : (0341) 558959

\section{CORRELATION BETWEEN SCENARIO QUALITY AND TUTORIAL DISCUSSION EFFECTIVENESS TO THE ACADEMIC ACHIEVMENT OF STUDENTS}

Lailia Izza Oktavia Purhadi, Rizki Anisa*, Marindra Firmansyah

Faculty of Medicine University of Islam Malang

\begin{abstract}
Introduction: Several internal and external factors affect student academic achievment, namely the PBL learning method, especially in terms of the scenario's quality level and the effectiveness of group discussions.

Method: Design descriptive-analytic study with cross sectional . Minimum sample size required in this study at least 490 samples. Bivariate analysis using the Spearman correlation test and the multiple linier regression test.

Results: This study has shown that in the spearmen correlation test, the P-value was obtained $<0.05$. It is proving a correlation between the quality of the scenario and the score of the Academic Achievement. For the effectiveness of the discussion, resulted the block value, namely P-value $<0.05$, it means that there is a correlation between the effectiveness of the discussion and the score of the Academic Achievement.

Subsequently, the multiple linier regression test reveals resulted that the discussion's effectiveness has a significant effect than the quality of the scenario on the score of Academic Achievement with P-value <0.05 Conclusion: There is a correlation between the quality of the scenario and the effectiveness of the discussion on Academic Achievement. The effectiveness of the discussion has a more significant effect than the quality of the scenario on the score of Academic Achievement.
\end{abstract}

Keywords: Academic Achievment, quality of scenarios, effectiveness of tutorial discussion.

Corresponding author :

Rizki Anisa

Jl. MT. Haryono 193 Malang City, East Java, Indonesia,65144 email :

rizky.anisa@unisma.ac.id,phone:(0341) 558959 


\section{PENDAHULUAN}

Akreditasi merupakan suatu penilaian kualitas terhadap sebuah institusi termasuk perguruan tinggi. Menurut Permenristekdikti No. 32 Tahun 2016, akreditasi adalah kegiatan penilaian untuk menentukan kelayakan dan mutu Program Studi dan Perguruan Tinggi. ${ }^{1}$ Fakultas Kedokteran Universitas Islam Malang (FK UNISMA) mempunyai akreditasi

B. Menurut Muhlisa (2018) terdapat beberapa peran mahasiswa yang dapat mempengaruhi peningkatan kualitas dan mutu suatu institusi, salah satunya adalah dalam prestasi akademik. Prestasi akademik adalah indikator yang menunjukkan suatu pencapaian tingkat keberhasilan dari proses pembelajaran yang telah dilakukan oleh mahasiswa secara optimal. ${ }^{2}$ Analisa prestasi akademik di FK UNISMA diukur menggunakan IP (Indeks Prestasi) yang diperoleh dari akumulasi nilai Ujian Mingguan, Ujian Responsi, OSCE, dan Ujian Akir Blok. Berdasarkan data statistik nilai yang diperoleh dari bagian akademik FK UNISMA didapatkan bahwa, sebagian besar mahasiswa memperoleh IP $<2$ sejumlah $60 \%$. Dengan demikian prestasi akademik mahasiswa FK UNISMA menunjukkan masih kurang optimal.

Berdasarkan teori Causal Model of PBL oleh Wim Gijselaers, 1990 bahwa terdapat beberapa faktor yang mempengaruhi prestasi akademik, salah satunya metode pembelajaran Problem Based Learning (PBL). PBL merupakan suatu metode instruksional yang menantang mahasiswa untuk belajar, bekerja sama dalam kelompok sehingga mendapatkan solusi untuk memecahkan masalah dari kasus yang ada. Masalah tersebut digunakan untuk mengaktifkan pengetahuan mereka sebelumnya. ${ }^{3}$ Berdasarkan penelitian dari Nurfitriani (2020) menyatakan proses pembelajaran PBL metode konstruktif dan kontekstual mempunyai hubungan yang signifikan terhadap performa akademik. ${ }^{4}$ Penelitian ini diperkuat oleh penelitian dari Muhammad (2020) yang menyatakan bahwa terdapat hubungan yang signifikan antara implementasi SPICES dengan Indeks Prestasi mahasiswa FK UNISMA. ${ }^{4}$ Selain PBL dengan metode konstruktif, kontekstual dan SPICES, terdapat beberapa proses PBL yang perlu dievaluasi yaitu terkait dengan komponen PBL yang lain yaitu prior knowledge dan motivasi mahasiswa, kualitas skenario, keefektifan diskusi, kemampuan reporting dan kinerja tutor.

Dengan kualitas skenario yang baik, mahasiwa lebih mudah dan tertarik memahami suatu kasus, sehingga nantinya akan mempengaruhi prestasi dari mahasiswa. Hal ini sesuai dengan studi yang dilakukan oleh Mewo (2018) menyatakan bahwa kualitas skenario yang baik dapat mempengaruhi prestasi akademik mahasiswa. Diskusi PBL efektif juga dapat meningkatkan proses pembelajaran yang mendalam bagi mahasiswa. ${ }^{6}$ Berdasarkan penelitian keefektifan diskusi kelompok terhadap prestasi belajar mahasiswa yang dilakukan oleh Sigit tahun 2016 didapatkan hasil bahwa keefektifan diskusi kelompok berpengaruh terhadap nilai ujian blok mahasiswa FKIK Untad. ${ }^{6}$

Prestasi akademik pada penelitian ini di interpretasikan dengan nilai Ujian Akhir Blok (UAB). Peneliti menggunakan nilai Ujian Akhir Blok karena bahan materi UAB mengacu pada LO (Learning
Objective) saat tutorial PBL. Berdasarkan paparan diatas, peneliti ingin melihat hubungan keefektifan diskusi dan kualitas skenario dengan prestasi akademik mahasiswa FK UNISMA.

\section{METODE PENELITIAN}

\section{Desain, Tempat, dan Waktu Penelitian}

Desain pada penelitian ini adalah cross sectional. Penelitian ini dilakukan pada periode Mei- Juni 2020 secara online dikarenakan pandemi covid- 19.

\section{Sampel}

Sampel dalam penelitian ini adalah mahasiswa Prodi Sarjana Kedokteran FK UNISMA angkatan 2017 (Kelas 3), 2018 (Kelas 2), dan 2019 (Kelas 1). Kriteria inklusi pada penelitian ini adalah seluruh mahasiswa yang mengikuti blok yang akan diteliti sedangkan kriteria eksklusinya adalah mahasiswa yang cuti atau tidak aktif mengikuti kegiatan akademik dan mahasiswa yang tidak naik kelas.

\section{Instrumen Penelitian}

Penelitian ini menggunakan instrumen berupa kuesioner, variable kualitas skenario menggunakan kuesioner Evaluate the Quality of PBL Problems sebagai dasar untuk mengevaluasi kualitas skenario PBL yang dikembangkan oleh Munshi et al, 2008 dan telah diadaptasi oleh Mewo, et al 2018 di Fakultas Kedokteran Universitas Sam Ratulangi. Sedangkan kuesioner kefektifan diskusi yaitu Tutorial Group Effectiveness Instrument (TGEI) yang dikembangkan oleh Singaram et al, 2010 dan telah diadaptasi oleh Mewo et al, 2016 di Fakultas Kedokteran Universitas Sam Ratulangi. ${ }^{5,7}$

Uji validitas kuesioner dilakukan kepada mahasiswa diluar sampel sebanyak 30 orang dan dianalisis uji validitas dan reabilitas dengan koefisiensi cronbach alpha $=0,84 \mathrm{r}=0,28$ didapatkan hasil valid dan reliabel.

\section{Pengambilan Data Kuesioner}

Pengambilan data kuesioner dilakukan terhadap responden mahasiswa dengan pengisian kuesioner di google form dan dipantau pengerjaannya melalui Zoom. Pengerjaan dilakukan secara serentak tepat setelah berakhir suatu blok di periode Mei-Juni 2020.

Pengambilan data kuesioner dilakukan selama 40 menit dan dimulai dengan penjelasan terkait informed consent dan maksud dari pengisian kuesioner. Pengisian dijalankan dengan pantauan zoom sehingga pertanyaan yang kurang jelas dapat langsung ditanyakan pada kolom percakapan di zoom. Pemantauan ini juga berfungsi untuk memastikan bahwa responden bisa lebih konsentrasi dalam mengisi kuesioner.

\section{Pengambilan Data Nilai Ujian Akhir Blok}

Pengambilan data nilai UAB dilaksanakan pada dua blok yang berlangsung pada periode Mei- Juni 2020 kelas 1, 2, dan 3. Nilai blok ini diperoleh dari ketua prodi dengan menyertakan syarat administrasi yang berlaku.

\section{Uji Layak Etik}

Penelitian ini telah disetujui secara etik oleh Komisi Etik Penelitian Fakultas Kedokteran Universitas Islam Malang No.008/LE.003/VII/02/2020 


\section{Teknik Analisa Data}

Analisa data menggunakan analisis bivariate. Uji yang digunakan dalam penelitian ini yaitu uji komparasi tidak berpasangan dengan uji korelasi Spearman dan uji regresi linier berganda serta menggunakan aplikasi Statistical Package for the Social Sciences (SPSS) versi 23 untuk pengolahan data statistic.

\section{HASIL DAN ANALISA DATA Hasil Karateristik Responden}

Pengambilan sampel menggunakan purposive sampling. Penghitungan sampel dilakukan dengan rumus Krejcie dan Morgan didapatkan hasil besar sampel minimal yang diperlukan untuk kelas 3 berjumlah minimal 72 sampel, kelas 2 berjumlah minimal 88 sampel, kelas 1 berjumlah minimal 72 sampel.

Jumlah keseluruhan sampel sebanyak 246 orang, terdiri dari mahasiswa-kelas 3 sejumlah 72, kelas 2 sejumlah 88 dan kelas 1 sejumlah 86. Karakteristik responden didapatkan dari data kuesioner meliputi usia, jenis kelamin, Indeks Prestasi (IP) dan keikutsertaan mengikuti Ujian Akhir Blok (UAB) terdapat pada Tabel 1
Tabel. 1 Karakteristik Responden Berdasarkan Usia dan Jenis KelamiKeterangan: Tabel 1 menunjukkan usia dan jenis kelamin responden

Berdasarkan Tabel $\mathbf{1}$ didapatkan. responden

\begin{tabular}{lc}
\hline Karakteristik & $\mathbf{n}$ \\
\hline Usia & \\
\hline $17-18$ & $11(4,5 \%)$ \\
\hline $19-20$ & $128(52 \%)$ \\
\hline $21-22$ & $106(43 \%)$ \\
\hline$\geq 23$ & $1(0,5 \%)$ \\
\hline Total & $246(100 \%)$ \\
\hline Jenis Kelamin & \\
\hline Laki-Laki & $68(27,6 \%)$ \\
\hline Perempuan & $178(72,4 \%)$ \\
\hline Total & $246(100 \%)$ \\
\hline
\end{tabular}

terbanyak berusia 19-20 tahun sebanyak 128 orang dan paling sedikit berusia 23 tahun sebanyak 1 orang. Responden berjenis kelamin laki-laki sebanyak 68 orang sedangkan responden terbanyak adalah perempuan sebanyak 178 orang.

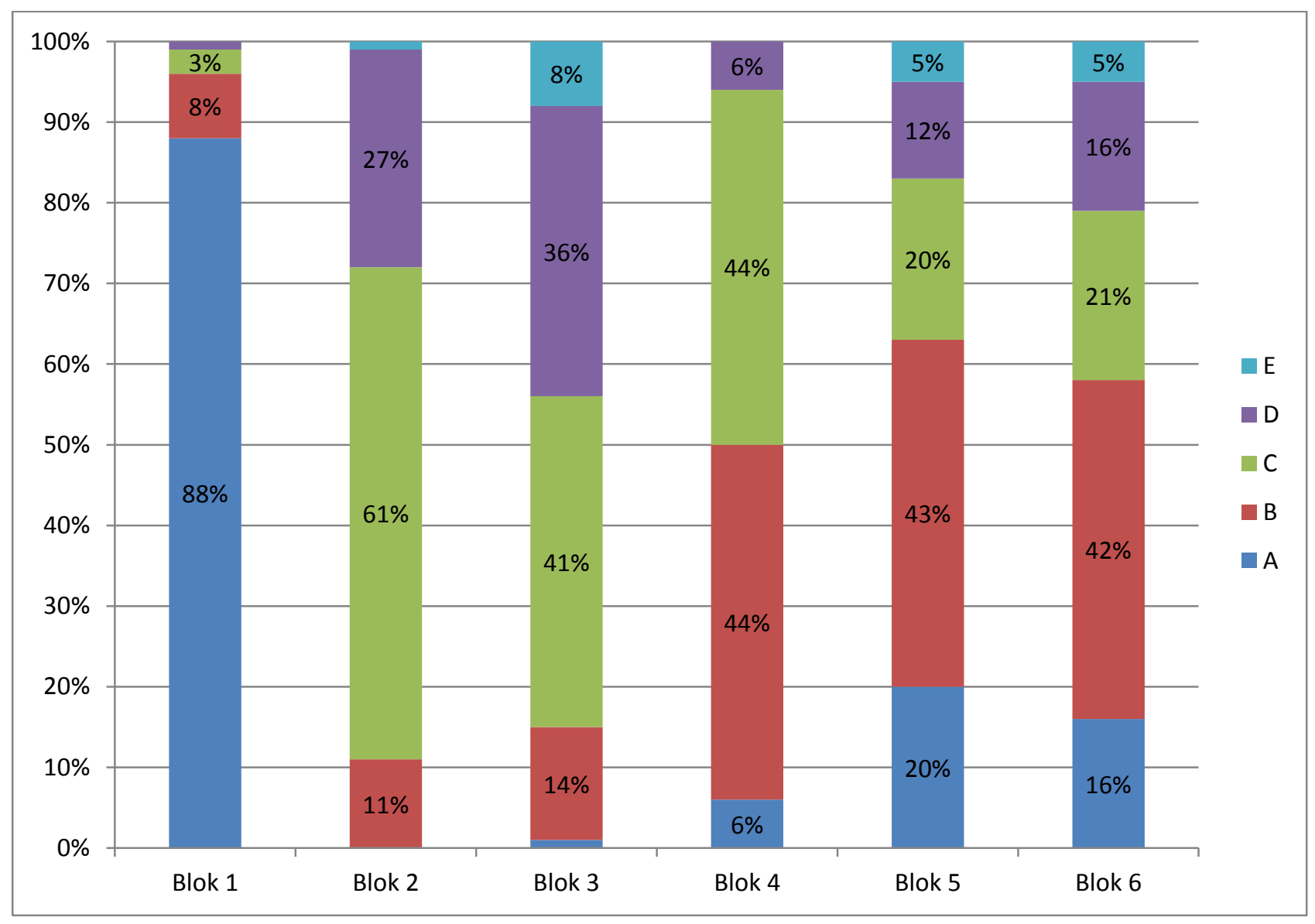

Gambar 1 Histogram Karateristik Responden Berdasarkan Hasil UAB

Keterangan: Gambar diatas menunjukkan setiap blok memiliki Nilai UAB yang berbeda beda

Pada Gambar 1 diketahui bahwa hasil UAB Mahasiswa yang mendapat nilai A terbanyak yaitu blok 1 sebanyak 63 mahasiswa $(88 \%)$, nilai B terbanyak diperoleh blok 4 sebanyak 39 mahasiswa (44\%), nilai C terbanyak diperoleh blok 6 sebanyak 46 mahasiswa $(61 \%)$, nilai D terbanyak diperoleh blok 3 sebanyak 32 mahasiswa (36\%) dan nilai E terbanyak didapat oleh blok 3 sebanyak 7 mahasiswa (8\%). 


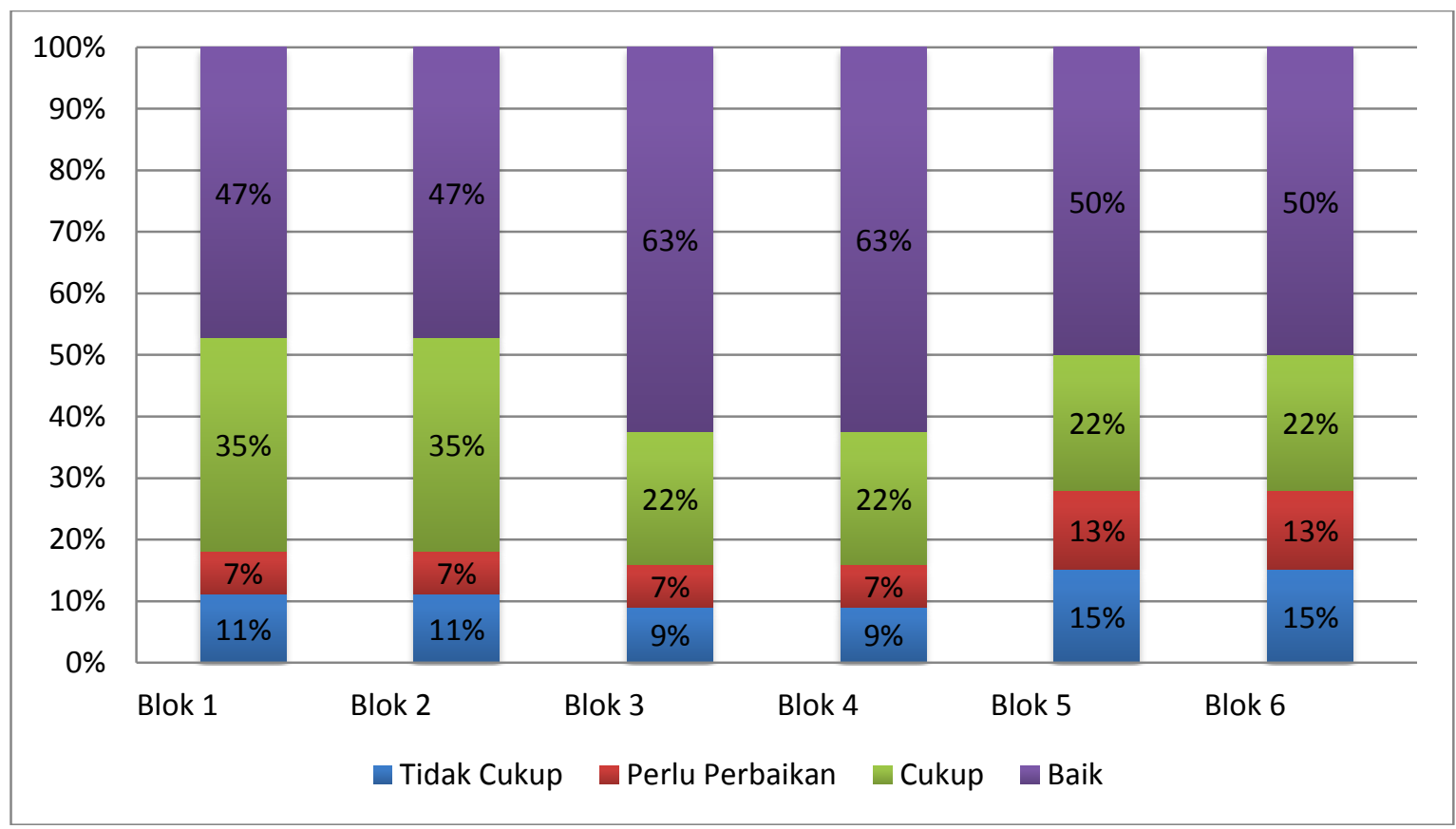

Gambar 2 Histogram Kualitas Skenario Berdasarkan Karateristik Responden

Keterangan: Hasil Kualitas Skenario Per Blok untuk mengetahui apakah kualitas skenario baik menurut responden

Berdasarkan data yang disajikan pada Gambar 2 dari keseluruhan responden, 50\% responden menyatakan kualitas skenario di FK UNISMA baik, dimana kualitas skenario terbaik didapatkan oleh Blok 3 (63\%). Sementara 15\% responden menyatakan kualitas skenario tidak cukup baik pada Blok $6(15 \%)$.

\subsection{Korelasi Kualitas Skenario terhadap Nilai Ujian Akhir Blok(UAB).}

Tabel 2 Uji Spearman Korelasi Kualitas Skenario terhadap Nilai UAB

\begin{tabular}{|c|c|c|c|c|c|c|c|c|c|}
\hline \multirow[t]{3}{*}{ Blok } & \multirow[t]{3}{*}{ KS } & \multicolumn{5}{|c|}{ UAB } & \multirow[t]{3}{*}{ Total } & \multirow[t]{3}{*}{$(R)$} & \multirow[t]{3}{*}{$P v$} \\
\hline & & $\mathbf{E}$ & D & $\mathrm{C}$ & B & $\mathbf{A}$ & & & \\
\hline & & $\mathrm{n}$ & $\mathrm{N}$ & $\mathrm{n}$ & $\mathrm{n}$ & $\mathrm{n}$ & & & \\
\hline \multirow[t]{4}{*}{1} & B & 0 & $1(1 \%)$ & 0 & $2(3 \%)$ & $31(43 \%)$ & $34(47 \%)$ & \multirow[t]{4}{*}{$0,28 * *$} & \multirow[t]{4}{*}{0,044} \\
\hline & $\mathrm{C}$ & 0 & 0 & $1(1 \%)$ & 0 & $24(34 \%)$ & $25(35 \%)$ & & \\
\hline & $\mathrm{PP}$ & 0 & 0 & 0 & $1(1 \%)$ & $4(6 \%)$ & $5(7 \%)$ & & \\
\hline & TC & 0 & 0 & $1(1 \%)$ & $3(4 \%)$ & $4(6 \%)$ & $8(11 \%)$ & & \\
\hline \multirow[t]{4}{*}{2} & B & 0 & $6(8 \%)$ & $24(33 \%)$ & $4(6 \%)$ & 0 & $34(47 \%)$ & \multirow[t]{4}{*}{$0,337 * *$} & \multirow[t]{4}{*}{0,004} \\
\hline & $\mathrm{C}$ & 0 & $5(7 \%)$ & $17(24 \%)$ & $3(4 \%)$ & 0 & $25(35 \%)$ & & \\
\hline & $\mathrm{PP}$ & 0 & $2(3 \%)$ & $3(4 \%)$ & 0 & 0 & $5(7 \%)$ & & \\
\hline & $\mathrm{TC}$ & $1(1 \%)$ & $6(9 \%)$ & $1(1 \%)$ & 0 & 0 & $8(11 \%)$ & & \\
\hline \multirow[t]{4}{*}{3} & $\mathrm{~B}$ & $1(1 \%)$ & $18(20)$ & $27(5 \%)$ & $8(9 \%)$ & $1(1 \%)$ & $55(63 \%)$ & \multirow[t]{4}{*}{$0,3^{* *}$} & \multirow[t]{4}{*}{0,005} \\
\hline & $\mathrm{C}$ & $2(2 \%)$ & $9(10 \%)$ & $5(5 \%)$ & $3(3 \%)$ & 0 & $19(22 \%)$ & & \\
\hline & $\mathrm{PP}$ & 0 & $2(2 \%)$ & $3(3 \%)$ & $1(1 \%)$ & 0 & $6(7 \%)$ & & \\
\hline & $\mathrm{TC}$ & $4(5 \%)$ & $3(3 \%)$ & $1(1 \%)$ & 0 & 0 & $8(9 \%)$ & & \\
\hline \multirow[t]{4}{*}{4} & $\mathrm{~B}$ & $2(2 \%)$ & $7(8 \%)$ & $14(16 \%)$ & $22(25 \%)$ & $10(11 \%)$ & $55(62 \%)$ & \multirow[t]{4}{*}{$0,24 * *$} & \multirow[t]{4}{*}{0,024} \\
\hline & $\mathrm{C}$ & 0 & $4(5 \%)$ & $5(6 \%)$ & $7(8 \%)$ & $3(3 \%)$ & $19(21 \%)$ & & \\
\hline & $\mathrm{PP}$ & 0 & $1(1 \%)$ & $2(2 \%)$ & $3(4 \%)$ & 0 & $6(7 \%)$ & & \\
\hline & $\mathrm{TC}$ & $1(1 \%)$ & $3(3 \%)$ & $4(5 \%)$ & 0 & 0 & $8(9 \%)$ & & \\
\hline \multirow[t]{4}{*}{5} & $\mathrm{~B}$ & 0 & $8(9 \%)$ & $8(9 \%)$ & $16(19 \%)$ & $11(13 \%)$ & $43(50 \%)$ & \multirow[t]{4}{*}{$0,262 * *$} & \multirow[t]{4}{*}{0,015} \\
\hline & $\mathrm{C}$ & $1(1 \%)$ & $1(1 \%)$ & $5(6 \%)$ & $10(12 \%)$ & $2(2 \%)$ & $19(22 \%)$ & & \\
\hline & $\mathrm{PP}$ & 0 & $1(1 \%)$ & $2(3 \%)$ & $7(8 \%)$ & $1(1 \%)$ & $11(13 \%)$ & & \\
\hline & $\mathrm{TC}$ & $3(3 \%)$ & $4(5 \%)$ & $3(3 \%)$ & $3(4 \%)$ & 0 & $13(15 \%)$ & & \\
\hline \multirow[t]{4}{*}{6} & $\mathrm{~B}$ & 0 & 0 & $6(7 \%)$ & $18(21 \%)$ & $19(22 \%)$ & $43(50 \%)$ & \multirow[t]{4}{*}{$0,234 * *$} & \multirow[t]{4}{*}{0,03} \\
\hline & $\mathrm{C}$ & 0 & 0 & $3(4 \%)$ & $8(9 \%)$ & $8(9 \%)$ & $19(22 \%)$ & & \\
\hline & $\mathrm{PP}$ & 0 & $1(2 \%)$ & $1(1 \%)$ & $3(3 \%)$ & $6(7 \%)$ & $11(13 \%)$ & & \\
\hline & $\mathrm{TC}$ & $1(1 \%)$ & 0 & $6(7 \%)$ & $5(6 \%)$ & $1(1 \%)$ & $13(15 \%)$ & & \\
\hline
\end{tabular}

Keterangan: Tabel 2 merupakan hasil analisa menggunakan uji Spearman yang menunjukkan adanya 
hubungan yang signifikan antara Keefektifan diskusi dan nilai UAB menggunakan uji Spearman $\mathrm{p}<0,05$. Persentase dihitung dari populasi total peserta blok.

Blok 1 (Psikiatri), Blok 2 (Life Cycle 2), Blok 3 (Patologi Respirasi), Blok 5 (Patologi Mata dan THT), Blok 6 (Muscukoskletal), Blok 7 (Cardiorespiratory), Blok 8 (Keefektifan Diskusi), E (Efektif), KE (Kurang Efektif)

Berdasarkan data yang disajikan pada Tabel 2 dari keseluruhan responden, Blok terbanyak yang menyatakan kualitas skenario baik adalah blok 3 dengan persentase $63 \%$, namun nilai terbanyak yang menyatakan kualitas skenario baik adalah Nilai A sebanyak $31(43 \%)$ pada Blok 1. Nilai terbanyak yang menyatakan kualitas skenario cukup adalah Nilai A sebanyak $24(34 \%)$ pada Blok 1. Nilai terbanyak yang menyatakan kualitas skenario perlu perbaikan adalah Nilai B sebanyak 16 (19\%) pada Blok 5. Nilai terbanyak yang menyatakan kualitas skenario tidak cukup adalah
Nilai C sebanyak $6(7 \%)$ pada Blok 6. Hasil uji Spearman didapatkan nilai $\mathrm{p}<0.05$ pada semua blok maka dapat diambil kesimpulan terdapat hubungan antara kualitas skenario dengan nilai Ujian Akhir Blok. Nilai $p$ bernilai positif sehingga arah korelasi adalah positif yang artinya semakin baik kualitas skenario maka akan semakin tinggi pula pencapaian nilai yang diperoleh pada ujian akhir bloknya. Nilai $\mathrm{R}$ didapatkan $<0.3$ pada semua blok, artinya korelasi yang didapatkan antara kualitas skenario terhadap nilai UAB lemah

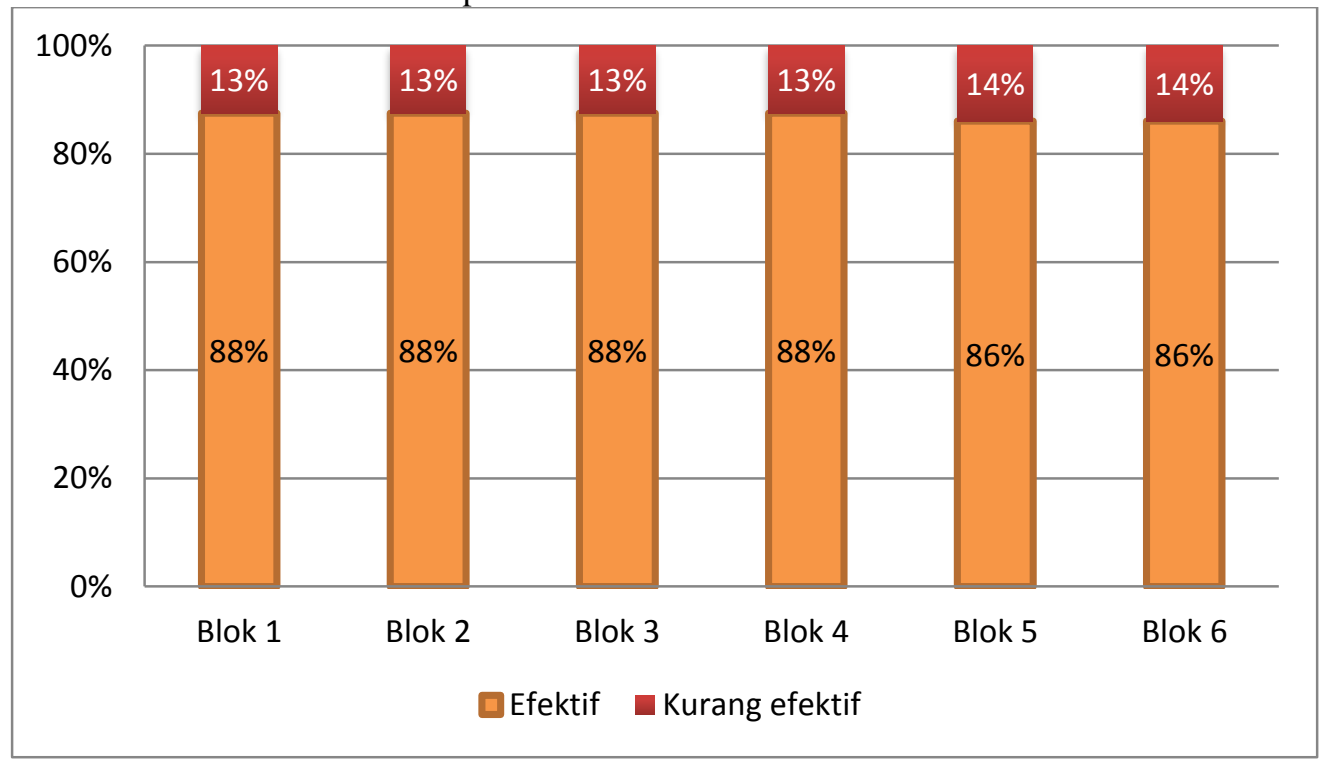

\section{Gambar 3 Histogram Hasil Keefektifan Diskusi Per Blok Menurut Responden}

Keterangan: Hasil Keefektifan Diskusi Per Blok untuk mengetahui apakah diskusi tutorial efektif menurut responden

Berdasarkan data yang disajikan pada Gambar 3 dari keseluruhan responden, $88 \%$ responden menyatakan diskusi tutorial di FK UNISMA efektif, dimana diskusi yang paling efektif didapatkan pada Blok 1. Sementara $16 \%$ responden menyatakan diskusi tutorial tidak efektif pada Blok 6.

\section{Hasil korelasi Keefektifan Diskusi terhadap Nilai Ujian Akhir Blok (UAB)}

Tabel 3 Uji Spearman Korelasi Keefektifan Diskusi terhadap Nilai UAB

\begin{tabular}{|c|c|c|c|c|c|c|c|c|c|}
\hline \multirow[t]{3}{*}{ Blok } & \multirow[t]{3}{*}{ KD } & \multicolumn{5}{|c|}{ UAB } & \multirow[t]{2}{*}{ Total } & \multirow[t]{2}{*}{$\boldsymbol{R}$} & \multirow[t]{2}{*}{$P v$} \\
\hline & & $\mathbf{E}$ & D & $\mathbf{C}$ & B & A & & & \\
\hline & & $\mathrm{N}$ & $\mathrm{n}$ & $\mathrm{n}$ & $\mathrm{N}$ & $\mathrm{n}$ & & & \\
\hline \multirow[t]{2}{*}{1} & $\mathrm{KE}$ & 0 & 0 & $\begin{array}{l}2(2, \\
8 \%)\end{array}$ & $\begin{array}{l}2(2, \\
7 \%)\end{array}$ & $5(7 \%)$ & $\begin{array}{c}9(12, \\
5 \%)\end{array}$ & $\mathbf{0 , 3 7 1} * *$ & 0,001 \\
\hline & $E$ & 0 & $\begin{array}{l}1(1, \\
4 \%)\end{array}$ & 0 & $\begin{array}{l}4(5, \\
6 \%) \\
\end{array}$ & $\begin{array}{c}58(80, \\
5 \%)\end{array}$ & $\begin{array}{c}63(87, \\
5 \%)\end{array}$ & & \\
\hline \multirow[t]{2}{*}{2} & $\mathrm{KE}$ & 0 & $\begin{array}{l}7(9, \\
7 \%)\end{array}$ & $\begin{array}{l}2(2, \\
8 \%) \\
\end{array}$ & 0 & 0 & $\begin{array}{c}9(12, \\
5 \%) \\
\end{array}$ & $0,39 * *$ & 0,001 \\
\hline & $\mathrm{E}$ & $\begin{array}{l}1(1, \\
4 \%)\end{array}$ & $\begin{array}{c}12(16, \\
7 \%)\end{array}$ & $\begin{array}{c}43(59, \\
7 \%)\end{array}$ & $\begin{array}{l}7(9, \\
7 \%)\end{array}$ & 0 & $\begin{array}{c}63(87, \\
5 \%)\end{array}$ & & \\
\hline \multirow[t]{2}{*}{3} & $\mathrm{KE}$ & $\begin{array}{l}4(4, \\
6 \%)\end{array}$ & $\begin{array}{l}6(6, \\
8 \%)\end{array}$ & $\begin{array}{l}1(1, \\
1 \%)\end{array}$ & 0 & 0 & $\begin{array}{c}11(12, \\
5 \%)\end{array}$ & $0,396 * *$ & 0,000 \\
\hline & $\mathrm{E}$ & $\begin{array}{l}3(3, \\
4 \%)\end{array}$ & $\begin{array}{c}26(29, \\
5 \%)\end{array}$ & $\begin{array}{c}35(39, \\
7 \%)\end{array}$ & $\begin{array}{c}12(13, \\
5 \%)\end{array}$ & $\begin{array}{l}1(1, \\
1 \%)\end{array}$ & $\begin{array}{c}77(87, \\
5 \%)\end{array}$ & & \\
\hline \multirow[t]{2}{*}{4} & $\mathrm{KE}$ & $1(1 \%)$ & $\begin{array}{l}6(6, \\
8 \%) \\
\end{array}$ & $\begin{array}{l}2(2, \\
3 \%) \\
\end{array}$ & $\begin{array}{l}2(2, \\
3 \%) \\
\end{array}$ & 0 & $\begin{array}{c}11(12, \\
5 \%)\end{array}$ & $\mathbf{0 , 3 3 9} * *$ & 0,001 \\
\hline & $\mathrm{E}$ & $\begin{array}{l}2(2, \\
3 \%)\end{array}$ & $\begin{array}{l}9(10 \\
, 2 \%) \\
\end{array}$ & $\begin{array}{c}23(26, \\
2 \%)\end{array}$ & $\begin{array}{l}30(3 \\
4 \%)\end{array}$ & $\begin{array}{c}13(14, \\
7 \%)\end{array}$ & $\begin{array}{c}77(87, \\
5 \%)\end{array}$ & & \\
\hline
\end{tabular}




\begin{tabular}{ccccccccc}
\hline 5 & $\mathrm{KE}$ & $2(2$, & $5(6 \%)$ & $4(4$, & $1(1 \%)$ & 0 & $12(13$, & $\mathbf{0 , 4 1 8 * *} 0,000$ \\
& & $3 \%)$ & & $6 \%)$ & & & $9 \%)$ & \\
& \multirow{2}{*}{$\mathrm{E}$} & $2(2$, & $9(10$, & $14(16$, & $35(40$, & $14(16$, & $74(86$, & \\
& $3 \%)$ & $5 \%)$ & $3 \%)$ & $7 \%)$ & $3 \%)$ & $5 \%)$ & \\
\hline \multirow{2}{*}{6} & $\mathrm{KE}$ & 0 & $1(1$, & $7(8$, & $4(4$, & 0 & $12(13$, & $\mathbf{0 , 4 4 1 * *} 0,000$ \\
& & & $2 \%)$ & $1 \%)$ & $6 \%)$ & & $9 \%)$ & \\
& $\mathrm{E}$ & $1(1$, & 0 & $9(10$, & $30(3$ & $34(39$, & $74(86$, & \\
& $2 \%)$ & & $7 \%)$ & $5 \%)$ & $6 \%)$ & $5 \%)$ & \\
\hline
\end{tabular}

Keterangan : Tabel 3 merupakan hasil analisa menggunakan uji Spearman yang menunjukkan adanya hubungan yang signifikan antara Keefektifan diskusi dan nilai UAB menggunakan uji Spearman $\mathrm{p}<0,05$. Persentase dihitung dari populasi total peserta blok. Blok 1 (Psikiatri), Blok 2 (Life Cycle 2), Blok 3 (Patologi Respirasi), Blok 5 (Patologi Mata dan THT), Blok 6 (Muscukoskletal), Blok 7 (Cardiorespiratory), Blok 8 (Keefektifan Diskusi), E (Efektif), KE (Kurang Efektif)

Berdasarkan data yang disajikan pada Tabel 5 dari keseluruhan responden, blok terrbanyak yang menyatakan diskusi tutorial efektif adalah blok 1 sebanyak $58(80,5 \%)$, sementara nilai terbanyak yang menyatakan diskusi tutorial efektif adalah Nilai A sebanyak $121(24,6 \%)$ pada blok 1 . Nilai terbanyak yang menyatakan diskusi tutorial kurang efektif adalah nilai $\mathrm{C}$ sebanyak $32(6,5 \%)$ pada blok 5.

Hasil Uji Spearman didapatkan bahwa $\mathrm{p}<$
0.05, maka dapat diambil kesimpulan bahwa terdapat hubungan antara kefektifan diskusi dengan nilai Ujian Akhir Blok. Nilai $p$ bernilai positif sehingga arah korelasi adalah positif yang artinya semakin efektif diskusi tutorial maka akan semakin tinggi pula pencapaian nilai yang diperoleh pada ujian akhir bloknya. Nilai $\mathrm{R}$ didapatkan 0,3-0,5 yang artinya korelasi antara keefektifan diskusi terhadap nilai ujian akhir blok cukup lemah.

Tabel 4 Tingkat Efektifitas Diskusi PerBlok Berdasarkan Aspek

\begin{tabular}{lllll}
\hline Blok & & & Keefektifan Diskusi & \\
\cline { 2 - 5 } Blok 1 & Aspek & Efektif & Kurang Efektif & Total \\
& $\mathrm{M}$ & $(\mathrm{n}=\%)$ & $(\mathrm{n}=\%)$ & $(\mathrm{n}=\%)$ \\
& $\mathrm{K}$ & $67(89 \%)$ & $8(11 \%)$ & $75(100 \%)$ \\
\hline Blok 2 & $65(86 \%)$ & $10(14 \%)$ & $75(100 \%)$ \\
& $\mathrm{D}$ & $46(62 \%)$ & $29(38 \%)$ & $75(100 \%)$ \\
\hline Blok 3 & $\mathrm{M}$ & $68(94 \%)$ & $4(6 \%)$ & $72(100 \%)$ \\
& $\mathrm{K}$ & $66(91 \%)$ & $6(9 \%)$ & $72(100 \%)$ \\
& $\mathrm{D}$ & $62(86 \%)$ & $10(14 \%)$ & $88(100 \%)$ \\
\hline Blok 4 & $\mathrm{M}$ & $73(82 \%)$ & $15(18 \%)$ & $88(100 \%)$ \\
& $\mathrm{K}$ & $74(84 \%)$ & $14(16 \%)$ & $88(100 \%)$ \\
\hline Blok 5 & $\mathrm{D}$ & $58(65 \%)$ & $30(35 \%)$ & $92(100 \%)$ \\
& $\mathrm{M}$ & $87(94,5 \%)$ & $5(6 \%)$ & $92(100 \%)$ \\
& $\mathrm{K}$ & $75(81 \%)$ & $17(19 \%)$ & $92(100 \%)$ \\
\hline Blok 6 & $\mathrm{D}$ & $50(54 \%)$ & $42(46 \%)$ & $75(100 \%)$ \\
& $\mathrm{M}$ & $57(76 \%)$ & $17(24 \%)$ & $75(100 \%)$ \\
& $\mathrm{K}$ & $53(70 \%)$ & $22(30 \%)$ & $75(100 \%)$ \\
\hline Keter & $48(64 \%)$ & $27(36 \%)$ & $86(100 \%)$ \\
& $\mathrm{D}$ & $77(89 \%)$ & $9(11 \%)$ & $86(100 \%)$ \\
\hline
\end{tabular}

Keterangan: $\mathrm{M}=$ Motivasi, $\mathrm{K}=$ Kognitif, $D=$ Demotivational. Hasil Keefektifan Diskusi dilihat dari aspek Motivasi, Kognitif, dan Demotivational Mahasiswa dari masing masing blok 
Pada Tabel 4 menunjukkan tingkat efektivitas diskusi kelompok dalam tutorial menurut persepsi mahasiswa dari aspek motivasi, kognitif dan demotivational dari setiap blok. Ditinjau dari aspek motivasi didapatkan diskusi tutorial yang efektif terdapat pada blok 4 (96,4\%). Sementara dari aspek kognitif didapatkan diskusi tutorial efektif terdapat pada blok 2 (1\%). Sedangkan ditinjau dari aspek demotivational (partisipasi dan kepribadian) didapatkan diskusi tutorial yang efektif terdapat pada blok

\section{Tabel 5 Tingkat Efektifitas Diskusi PerAngkatan Berdasarkan Aspek}

\begin{tabular}{|c|c|c|c|c|}
\hline \multirow[t]{2}{*}{ Angkatan } & \multirow[b]{2}{*}{ Aspek } & \multicolumn{3}{|c|}{ Keefektifan Diskusi } \\
\hline & & Efektif & Kurang Efektif & Total \\
\hline & & $(\mathrm{n}=\%)$ & $(\mathrm{n}=\%)$ & $(\mathrm{n}=\%)$ \\
\hline \multirow[t]{3}{*}{2017} & M & $68(94 \%)$ & $4(6 \%)$ & $72(100 \%)$ \\
\hline & $\mathrm{K}$ & $66(91 \%)$ & $6(9 \%)$ & $72(100 \%)$ \\
\hline & $D$ & $62(86 \%)$ & $10(14 \%)$ & $72(100 \%)$ \\
\hline \multirow[t]{3}{*}{2018} & M & $84(95 \%)$ & $4(5 \%)$ & $88(100 \%)$ \\
\hline & $\mathrm{K}$ & $76(86 \%)$ & $12(14 \%)$ & $88(100 \%)$ \\
\hline & $D$ & $85(96,4 \%)$ & $3(4 \%)$ & $88(100 \%)$ \\
\hline \multirow[t]{3}{*}{2019} & M & $79(91 \%)$ & $7(9 \%)$ & $86(100 \%)$ \\
\hline & $\mathrm{K}$ & $76(88 \%)$ & $10(12 \%)$ & $86(100 \%)$ \\
\hline & $D$ & $52(60 \%)$ & $34(40 \%)$ & $86(100 \%)$ \\
\hline
\end{tabular}

Keterangan: $\quad \mathrm{M}=$ Motivasi,$\quad \mathrm{K}=$ Kognitif, $\quad D=$ Demotivational . Hasil Keefektifan

Diskusi dilihat dari aspek Motivasi, Kognitif, dan Demotivational Mahasiswa Per Angkatan.

Pada Tabel 5 menunjukkan tingkat efektivitas diskusi kelompok dalam tutorial menurut persepsi mahasiswa dari aspek motivasi, kognitif dan demotivational perangkatan. Ditinjau dari aspek motivasi, mahasiswa kelas $2(96,4 \%)$ berpendapat diskusi tutorial efektif. Sementara dari aspek kognitif, mahasiswa kelas $3(91 \%)$ berpendapat diskusi tutorial efektif.

\section{Hasil Perbedaan Kualitas Skenario, Keefektifan Diskusi dengan Nilai UAB Setiap Angkatan}

Tabel 6 Hasil Uji one way ANNOVA melihat perbedaan Kualitas Skenario, Keefektifan Diskusi terhadap Nilai UAB

\begin{tabular}{lll}
\hline Variable & F & Sig \\
\hline KF, KD & 0,158 & 0,305
\end{tabular}

Keterangan: Hasil nilai one way ANNOVA untuk mengidentifikasi apakah terdapat perbedaan antar kelompok yang diteliti.

Berdasarkan Tabel 6 tampak nilai p-value yang diperoleh kurang dari 0,05 dengan taraf signifikansi 5\%, sehingga dapat dikatakan bahwa ada perbedaan antara kualitas skenario dan keefektifan diskusi terhadap nilai ujian akhir blok.
Sedangkan ditinjau dari aspek demotivational (partisipasi dan kepribadian) didapatkan mahasiswa kelas $2(96 \%)$ berpendapat bahwa diskusi tutorial efektif . Dilihat dari tingkat keefektifan menurut aspek yang terbesar, yaitu aspek motivasi sebesar $96,4 \%$

Hasil Analisis faktor yang Berpengaruh antara Kualitas Skenario dan Keefektifan Diskusi terhadap Prestasi Akademik

Tabel 7 Hasil Uji Regresi Linier Berganda melihat

\begin{tabular}{lll}
\hline \multicolumn{1}{c}{ Variabel } & P-value & R Square \\
\cline { 1 - 1 } & & 0,213 \\
\cline { 1 - 2 } Kualitas Skenario & 0.235 & \\
\hline
\end{tabular}

\section{faktor yang paling berpengaruh}

Keterangan: Hasil nilai regresi linier berganda untuk mengidentifikasi manakah faktor yang paling berpengaruh

Pengaruh kualitas skenario dan keefektifan diskusi terhadap prestasi akademik dianalisis dengan menggunakan uji regresi linier berganda dan didapatkan nilai $P$ value $(0,00)$ atau $\mathrm{p}<0,05$ pada keefektifan diskusi. Sehingga dapat diambil kesimpulan bahwa keefektifan diskusi berpengaruh signifikan terhadap Prestasi Akademik Mahasiswa. Sementara pada Kualitas 
skenario didapatkan nilai $\mathrm{p}$ value $(0,235)$ atau $\mathrm{p}>0,05$ yang artinya kualitas skenario tidak berpengaruh signifikan terhadap prestasi akademik mahasiswa. Sementara nilai $R$ Square adalah 0,213 yang artinya keefektifan diskusi dan kualitas skenario mampu menjelaskan keberagaman dari prestasi akademik sebesar 21,3 sedangkan untuk 78,7\% dijelaskan oleh variable lain yang tidak diteliti.

Faktor lain yang dapat mempengaruhi prestasi akademik yang tidak diteliti dalam penelitian ini adalah prior knowledge bisa dilihat dari data IP mahasiswa sebelum dilakukan penelitian, kemudian presentasi kehadiran mahasiswa di tutorial ataupun dikelas, kesiapan akademik belajar mahasiswa, dan motivasi belajar dari mahasiswa itu sendiri.

\section{PEMBAHASAN}

Berdasarkan hasil nilai Ujian Akhir Blok, nilai A terbanyak terdapat pada blok 1 dan nilai E terbanyak didapat oleh blok Patologi 3. Menurut peneliti, adanya perbedaan nilai dari masing-masing blok disebabkan karena beberapa faktor seperti tingkat kesulitan yang berbeda-beda antar blok, dan perbedaan penataan strategi blok. Pada blok 1 mempunyai susunan strategi blok yang tertata dan materi Ujian Akhir Blok juga sesuai dengan Buku Petunjuk Blok. Pada Blok 1 juga materi yang diberikan lebih mudah dipahami, sedangkan materi pada blok 4 lebih banyak membutuhkan analisa, konsentrasi dan hapalan. Hasil penelitian ini sejalan dengan penelitian yang dilakukan oleh Nyimas dkk (2014) pada 198 mahasiswa semester 2, 4 dan 6 di Fakultas Kedokteran Universitas Jambi yang menunjukan bahwa terdapat hubungan yang bermakna antara mahasiswa terhadap lingkungan pembelajaran dengan strategi pembelajaran blok. Dengan semakin baik persepsi mahasiswa terhadap strategi pembelajaran blok, mahasiswa akan mendapat pencapaian akademik yang optimal ${ }^{8}$. Berdasarkan penelitian dari Daruyani, Wilandari (2013) di Universitas Diponogoro ada dua macam faktor yang dapat mempengaruhi prestasi belajar mahasiswa, yaitu faktor internal dan faktor eksternal. Faktor internal antara lain: intelegensi, konsep diri dan gaya belajar, sedangkan Fakor eksternal antara lain: keluarga, status sosial, lingkungan akademik dan lain sebagainya. Selain itu, cara belajar dari masing masing mahasiswa juga menjadi faktor lain yang menyebabkan perbedaan nilai UAB. ${ }^{9}$ Hal ini diperkuat oleh Syah (2008) yang menyebutkan bahwa selain faktor internal dan eksternal faktor pendekatan belajar juga merupakan salah satu faktor yang mempengaruhi belajar mahasiswa dalam mencapai prestasi akademik. ${ }^{10}$

\section{Distribusi Gambaran Penilaiain Kualitas Skenario}

Hasil penilaian kualitas skenario didapatkan bahwa responden terbanyak yang menyatakan kualitas skenario PBL baik terdapat pada Blok 3. Namun bila dihubungkan dengan nilai, responden yang memperoleh nilai A pada Blok 3 hanya sedikit. Hasil penelitian ini bertentangan dengan penelitian dari Mewo (2018) di FK Universitas Sam Ratulangi yang menyatakan bahwa kualitas skenario yang baik dapat mempengaruhi prestasi akademik mahasiswa FK Universitas Sam Ratulangi ${ }^{5}$. Hal ini disebabkan karena ada faktor lain yang mempengaruhi prestasi akademik selain kualitas skenario. Menurut Van Berkel dkk (2006) dalam penelitiannya mengatakan terdapat tiga faktor penting dalam strategi belajar PBL, yaitu masalah/kasus skenario, kinerja tutor, dan efektivitas diskusi kelompok. Kinerja tutor dan kualitas masalah saling berinteraksi dan memberi kontribusi dalam menciptakan keefektifan kelompok dan lingkungan belajar yang baik yang berefek positif terhadap pencapaian hasil belajar ${ }^{11}$. Teori Causal model of PBL dari Schmidt dan Gijselaers yang dikutip oleh Munshi menyatakan bahwa faktor faktor yang mempengaruhi prestasi akademik selain kualitas skenario adalah pengetahuan awal (prior knowledge), diskusi tutorial, dan prestasi tutor merupakan faktor yang penting dan berpengaruh dalam proses pembelajaran dan hasil akhir. $^{12}$

\section{Hubungan Kualitas Skenario terhadap Nilai UAB}

Hasil analisis korelasi kualitas Skenario terhadap Nilai UAB diperoleh bahwa terdapat korelasi antara keaktifan diskusi tutorial terhadap Nilai Ujian Akhir Blok. Hasil ini didukung oleh penelitian yang dilakukan oleh Van Berkel dkk (2006) dalam penelitian mereka mengatakan terdapat hubungan yang positif dan signifikan antara kualitas skenario dengan prestasi akademik. $^{11}$

Hasil penelitian Imelda dkk pada tahun 2016 di Universitas Padjajaran menunjukkan bahwa kualitas kasus skenario yang baik dapat memberikan dampak yang signifikan terhadap prestasi akademik. Kualitas skenario yang baik adalah skenario yang mampu mengarahkan mahasiswa sesuai dengan tujuan pembelajaran yang ada di buku blok sehingga keingintahuan mahasiswa terpacu ${ }^{18}$. Hal ini diperkuat oleh Norman GR (2000). Skenario yang bekualitas mampu merangsang dan memicu mahasiswa menjalankan pembelajaran dengan baik. Kualitas kasus dalam skenario dapat membantu mahasiswa memperoleh domain pengetahuan yang cukup, mengaktifkan pengetahuan sebelumnya, merangsang rasa ingin tau mahasiswa, dan mengarahkan proses belajar yang lebih baik. Dengan kata lain mahasiswa di stimulus belajar aktif sehinggan mendapatkan hasil ujian akhir yang baik. ${ }^{19}$

\section{Distribusi Gambaran Terkait Keefektifan Diskusi}

Sebagian besar responden menyatakan diskusi tutorial PBL efektif. Diskusi tutorial yang efektif terdapat pada blok 1, Hasil penelitian ini sesuai dengan prestasi yang dicapai mahasiswa pada Blok 1 karena sebagian besar mahasiswa memperoleh nilai A. Hal ini sesuai dengan penelitian Sigit (2016) yang membuktikan bahwa terdapat korelasi yang bermakna antara keaktifan diskusi tutorial terhadap nilai ujian akhir blok mahasiswa Program Studi Kedokteran FK Untad $^{6}$. Jika dihubungkan dengan Causal Model of $P B L$, menurut Istadi (2008) terdapat beberapa komponen untuk meningkatkan prestasi akademik, yaitu efektifitas pembelajaran dalam sebuah diskusi tutorial, dan kinerja tutor.${ }^{15}$

Hubungan Keefektifan Diskusi terhadap Nilai UAB

Hasil analisis keaktifan diskusi tutorial terhadap nilai UAB menggunakan uji korelasi Spearman. didapatkan korelasi antara keaktifan 
diskusi tutorial terhadap Nilai Ujian Akhir Blok mahasiswa Program Studi Kedokteran Unisma.

Nilai $p(0,001)$ bernilai positif yang artinya semakin aktif seorang mahasiswa dalam melaksanakan diskusi tutorial maka akan semakin tinggi pula pencapaian nilai yang diperoleh pada ujian akhir bloknya.

Hasil penelitian ini sesuai dengan penelitian Sigit (2016) yang membuktikan bahwa terdapat korelasi yang bermakna antara keaktifan diskusi tutorial terhadap nilai ujian akhir blok mahasiswa Program Studi Kedokteran FKIK Untad. ${ }^{7}$ Hal ini membuktikan teori Causal Model of PBL bahwa terdapat beberapa faktor yang mempengaruhi prestasi akademik yaitu prior knowledge dan motivasi mahasiswa, kualitas skenario, keefektifan diskusi, kemampuan reporting dan kinerja tutor. Hal ini diperkuat oleh Koh, 2008 bahwa diskusi tutorial PBL selama masa pendidikan kedokteran memiliki efek positif terhadap prestasi akademik, khususnya pada dimensi sosial dan kognitifnya. Hal ini juga didukung oleh pernyataan Harsono bahwa diskusi tutorial di dalam kegiatan PBL akan mengaktifkan kelompok untuk mencapai kemajuan secara bermakna melalui pembahasan masalah yang tersaji, sehingga aktifitas ini merupakan salah satu jenis metode pendidikan untuk meningkatkan pembelajaran mahasiswa yang akan berpengaruh pada prestasi

pembelajaran mahasiswa. ${ }^{20,21}$

Uji beda dilakukan kepada masing-masing angkatan untuk melihat perbedaan antara kualitas skenario, keefektifan diskusi dengan nilai UAB antar angkatan. Jika varian dari nilai UAB, kualitas skenario dan keefektifan diskusi diasumsikan sama maka terdapat perbedaan pada nilai UAB antara angkatan 2017 dan 2018, karena nilai $\mathrm{p}<0.05$ namun, pada kualitas skenario tidak terdapat perbedaan karena nilai p $>0.05$. UAB angkatan 2018 dan 2019 juga terdapat perbedaan karena nilai $\mathrm{p}<0.05$ namun pada kualitas skenario dan keefektifan diskusi tidak terdapat perbedaan karena nilai $\mathrm{p}>0.05$. Terdapat perbedaan pada nilai keefekttifan diskusi antara angkatan 2017 dan 2019 karena nilai $\mathrm{p}<0.05$ namun pada UAB dan kualitas skenario tidak terdapat perbedaan karena nilai $\mathrm{p}>0.05$. Berdasarkan data tersebut sesuai penelitian Imelda (2016) menyatakan bahwa adanya perbedaan yang signifikan terhadap nilai UAB antar angkatan dikarenakan perbedaan tingkat kesulitan materi tiap angkatan dan kesiapan menghadapi ujian pada tiap angkatan. $^{18}$

\section{Hubungan yang Paling Berpengaruh antara Kualitas Skenario dan Keefektifan Diskusi terhadap Nilai UAB}

Berdasarkan Tabel 9 pada uji regresi linier berganda diketahui bahwa kualitas skenario dan keefektifan diskusi mempunyai pengaruh positif terhadap nilai UAB. Namun didapatkan nilai $\mathrm{p}<0,05$ pada keefektifan diskusi dan $\mathrm{p}>0,05$ pada kualitas skenario. Sehingga dapat disimpulkan bahwa keefektifan diskusi lebih berpengaruh signifikan dibandingkan kualitas skenario terhadap nilai UAB. Hal ini didukung oleh penelitian Sigit,2016 yang membuktikan bahwa terdapat korelasi yang bermakna antara keaktifan diskusi tutorial terhadap nilai ujian blok Immunology and Infection mahasiswa Program Studi Kedokteran FKIK Untad. Sehingga dapat diartikan bahwa kegiatan diskusi tutorial merupakan salah satu elemen esensial sistem pembelajaran PBL yang tidak dapat dilepaskan, karenanya salah satu usaha untuk membuat mahasiswa mencapai tujuan pembelajaran yang diinginkan oleh pendidik adalah dengan membuat mahasiswa tersebut semakin berperan aktif dalam diskusi tutorial. $^{6}$

Menurut Dolmans (1998) diskusi tutorial mempengaruhi pretasi akademik mahasiswa karena diskusi yang efektif mempengaruhi beberapa aspek dari dalam diri mahasiswa yaitu motivasional (motivasi dan kohesi), faktor kognitif (interaksi dan elaborasi), dan faktor demotivational (partisipasi dan kepribadian) Jika mahasiswa dapat berdiskusi dengan efektif, dapat disimpulkan bahwa mahasiswa sudah memahami materi tersebut dengan baik. ${ }^{16}$

Menurut Mewo (2008) tutorial adalah kunci keberhasilan metode PBL, Tutorial yang efektif akan menjamin pencapaian tujuan belajar. Keberhasilan mahasiswa dalam proses tutorial dapat dipengaruhi oleh beberapa faktor, antara lain pemahaman dan motivasi mahasiswa tersebut, kualitas skenario yang digunakan, keefektifan diskusi saat tutorial. dan peranan tutor sebagai fasilitator. Apabila faktor faktor tersebut dalam proses tutorial kurang, maka tutorial tidak akan efektif sehingga tujuan pembelajaran akan sulit dicapai. ${ }^{5}$ Faktor faktor yang mempengaruhi kesuksesan tutorial inilah yang disebut dengan Causal Model of PBL. Berdasarkan hasil penelitian ini faktor yang paling berpengaruh adalah Keefektifan Diskusi

\section{SIMPULAN}

Berdasarkan hasil penelitian dan pembahasan yang dilakukan mengenai hubungan antara Keefektifan Diskusi dan Kualitas Senario terhadap prestasi akademik Mahasiswa Fakultas Kedokteran Universitas Islam Malang, dapat disimpulkan sebagai berikut:

1. Terdapat korelasi antara kualitas skenario terhadap prestasi akademik dengan nilai $\mathrm{p}<0,05$

2. Terdapat korelasi antara keefektifan diskusi terhadap prestasi akademik dengan nilai $\mathrm{p}<0,05$

3. Keefektifan diskusi lebih berpengaruh signifikan dibandingkan kualitas skenario terhadap prestasi akademik dengan nilai $\mathrm{p} 0,00$

\section{SARAN}

Mengacu pada hasil penelitian, pembahasan serta kesimpulan maka dapat dikemukakan beberapa saran sebagai berikut:

1. Bagi peneliti selanjutnya agar lebih mendalam mencari faktor-faktor yang mempengaruhi

prestasi akademik melanjutkan penelitian ini menggunakan metode SEMPLS

2. Bagi pembaca dalam upaya meningkatkan prestasi akademik, sebaiknya tidak hanya fokus pada kesiapan belajar sebelum ujian saja namun pada faktor-faktor lain yang juga dapat mempengaruhi nilai UAB.

3. Bagi Institusi, agar penelitian ini dapat menjadi informasi tambahan dan masukan untuk meningkatkan prestasi akademik mahasiswa pada angkatan 
selanjutnya

\section{UCAPAN TERIMAKASIH}

Ucapan terima kasih disampaikan kepada IOM dan Fakultas Kedokteran Universitas Islam Malang yang telah mendanai penelitian ini.

\section{DAFTAR PUSTAKA}

[1] Permenristek Dikti Nomor 32 Tahun 2016. Akreditasi Prodi dan Perguruan Tinggi

[2] Muhlisa. Peran Mahasiswa dalam Penjaminan Mutu Perguruan Tinggi. Jurnal Kesehatan Poltekkes Ternate. 2018. 7(2):48

[3] Gijselaers W.H, Schmidt H.G. Development and Evaluation of a Causal Model of Problem- Based Learning. Springer; 1990. Available from: http://hdl.handle.net/1765/2776

[4] Nurfiriani A. Indria D M, Firmansyah M. Hubungan Proses Pembelajaran Berbasis Problem Based Learning (PBL) dengan Metode Konstruktif dan Kontekstual terhadap Performa Akademik Mahasiswa Kedokteran. Fakultas Kedokteran Unisma. Jurnal Biokomplementer Medicine. 2020; Hlm 7.

[5] Muhammad N U, Herlina S, Firmansyah M. Analisa Proses Pembelajaran Berbasis Student Centered Learning, Problem Based Learning, Integrated, Community Based Learning, Electives, Systematic (SPICES) Terhadap Indeks Prestasi Mahasiswa Fakultas Kedokteran. Universitas Islam Malang. Jurnal Biokomplementer Medicine. 2020; Hlm 6.

[6] Mewo Y, Widodo S, Prihartono J. Persepsi Mahasiswa Terhadap Efektivitas Kelompok Diskusi Tutorial Problem-Based Learning di Fakultas Kedokteran Universitas Sam Ratulangi Manado. J Perpipki. 2011;2:22-31.

[7] Sigit, Hubungan Keaktifan Diskusi Tutorial Terhadap Nilai Ujian Blok 8 (Immunology and Infection) Mahasiswa Program Studi Kedokteran Universitas Tadulako. Fakultas Kedokteran dan Ilmu Kesehatan Universitas Tadulako.2016. 8.

[8] Munshi F, Zayat E, Dolmans D. Develop- ment and utility of a questionnaire to evaluate the quality of PBL problems. South East Asian Journal of Medical Education. 2008;2(2):3-40.

[9] Nyimas N, Anwar J. Setyawati. Hubungan Persepsi Lingkungan Pembelajaran Dengan Strategi Pembelajaran Mahasiswa Program Studi Pendidikan Dokter Universtas Jambi. Fakultas Kedokteran dan Ilmu Kesehatan, Universitas Jambi. 2014. Hal. 36
[10] Daruyani S, Yuciana Wilandari dan Hasbi Yasin. Faktor-Faktor Yang Memepengaruhi Indeks Prestasi Mahasiswa FSM Universitas Diponegoro Semester Pertama dengan Metode Regresi Logistik Biner. Jurnal Gaussian, Vol2. FSM Undip; 2013.

[11] Syah, M. Psikologi Belajar. Jakarta: PT Raja Grafindo Persada. 2008

[12] Van Berkel The influence of tutoring competencies on problems, group functioning and student achievement in problem-based learning. Medical Education. 2006;40:730-6.

[13] Schmidt HG. Problem-based learning: Rationale and description. Medical Education. 1983;17:11- 6.

[14] Wood D. Problem-Based Learning. In: Cantillon $\mathrm{P}$, editor. ABC of learning and teaching in medicine. BMJ Books; 2003. p. 12-4.

[15] Ferreira, Maria M. dan Trudel, Anthony R. "The Impact of ProblemBased Learning (PBL) on Student Attitudes Toward Science, Problem-Solving Skills, and Sense of Community in the Classroom". Journal of Classroom Interaction Vol. 47, No.1. 2012;Hal. 23-30.

[16] Istadi Y. Hubungan antara Dimensi Perilaku Belajar Kelompok dengan Keefektifan

Kelompok Tutorial PBL. Majalah Ilmiah Sultan Agung. 2008 Sept; 49(125):39-45.

[17] Dolmans DHJM, Snellen-Balendong, H, Wolfhagen IHAP, Van der Vleuten CPM. Seven principles of effective case design for a problem based curriculum. Medical Teacher. 1998: 19(3):185-9.

[18] Yuan H, Williams B, Yin L, Liu M, Fang J, Pang D. Nursing students views on the effectiveness of problem-based learning. Nurse Educ Today. 2010;31:577-81

[19] Imelda M.G. Sianipar, Dany Hilmanto, Ike MP. Siregar, Farid Husin, Endang Sutedja. Hubungan Kinerja Tutor dan Kualitas Kasus Skenario Terhadap Keefektifan Kelompok pada Metode Belajar Problem Based Learning. Departemen Kulit dan Kelamin Fakultas Kedokteran Univeritas Padjadjaran. 2016

[20] Norman GR, Schmidt HG. Effectiveness of problembased learning curricula: theory, practice and paper darts. Med Educ. 2000 Sep;34(9):721-8.

[21] Koh GC-H, Khoo HE, Wong ML, Koh, D. The Effects of Problem-Based Learning During Medical School on Physician Competency: a Systematic Review. CMAJ Open. 2008 Jan; 178(01):34-41.

[22] Harsono. Hakekat student-centered learning. Yogyakarta: Pusat Pengembangan Pendidikan Universitas Gadjah Mada, 2006. 